The University of Maine

DigitalCommons@UMaine

Publications

Senator George J. Mitchell Center for Sustainability

Solutions

6-2015

\title{
Implications of species addition and decline for nutrient dynamics in freshwaters.
}

Krista A. Capps

Carla L.Atkinson

Amanda T. Rugenski

Follow this and additional works at: https://digitalcommons.library.umaine.edu/ mitchellcenter_pubs

\section{Repository Citation}

Capps, Krista A.; Atkinson, Carla L.; and Rugenski, Amanda T., "Implications of species addition and decline for nutrient dynamics in freshwaters." (2015). Publications. 31.

https://digitalcommons.library.umaine.edu/mitchellcenter_pubs/31

This Article is brought to you for free and open access by DigitalCommons@UMaine. It has been accepted for inclusion in Publications by an authorized administrator of DigitalCommons@UMaine. For more information, please contact um.library.technical.services@maine.edu. 


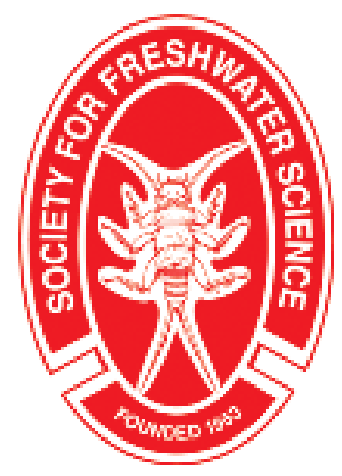

Implications of species addition and decline for nutrient dynamics in fresh waters Author(s): Krista A. Capps, Carla L. Atkinson, and Amanda T. Rugenski

Source: Freshwater Science, Vol. 34, No. 2 (June 2015), pp. 485-496

Published by: The University of Chicago Press on behalf of Society for Freshwater Science Stable URL: http://www.jstor.org/stable/10.1086/681095

Accessed: 20/06/2015 20:13

Your use of the JSTOR archive indicates your acceptance of the Terms \& Conditions of Use, available at http://www.jstor.org/page/info/about/policies/terms.jsp

JSTOR is a not-for-profit service that helps scholars, researchers, and students discover, use, and build upon a wide range of content in a trusted digital archive. We use information technology and tools to increase productivity and facilitate new forms of scholarship. For more information about JSTOR, please contact support@jstor.org. 


\title{
Implications of species addition and decline for nutrient dynamics in fresh waters
}

\author{
Krista A. Capps ${ }^{1,2,7}$, Carla L. Atkinson ${ }^{3,4,8}$, and Amanda T. Rugenski ${ }^{5,6,9}$ \\ ${ }^{1}$ Department of Ecology and Evolutionary Biology, Cornell University, Ithaca, New York 14850 USA \\ ${ }^{2}$ Sustainability Solutions Initiative, University of Maine, Orono, Maine 04463 USA \\ ${ }^{3}$ Oklahoma Biological Survey, Department of Biology and Ecology and Evolutionary Biology Graduate Program, \\ University of Oklahoma, Norman, Oklahoma 73019 USA \\ ${ }^{4}$ Department of Biological Sciences, University of Alabama, Tuscaloosa, Alabama 35487 USA \\ ${ }^{5}$ Department of Zoology and Center for Ecology, Southern Illinois University, Carbondale, Illinois 62901 USA \\ ${ }^{6}$ School of Life Sciences, Arizona State University, Tempe, Arizona 85281 USA
}

\begin{abstract}
In terrestrial and aquatic ecosystems, organisms directly affect nutrient storage and cycling by sequestering nutrients via growth and remineralizing nutrients via excretion and egestion. Therefore, species introductions and extirpations can profoundly affect nutrient storage and remineralization rates, and present a challenge for conserving ecosystem function in fresh waters. The literature of consumer-driven nutrient dynamics is growing rapidly, but studies of consumer effects on nutrient storage and remineralization across species and among ecosystems are limited. We compared the effects of 3 grazing taxa, nonnative armored catfish in Mexican streams, native mussels in Oklahoma streams, and native tadpoles in Panamanian streams, on nutrient storage and remineralization. We examined interactions among organismal stoichiometry and biomass, nutrient storage, remineralization rates, and ecosystem size across these 3 groups following species decline (tadpoles and mussels) or introduction (armored catfish) to gain a better understanding of organism-specific effects on nutrient dynamics among freshwater ecosystems. Collectively, our results suggest that the ecosystem-level effect of consumerdriven nutrient dynamics is strongly influenced by environmental variables and is taxon specific. Major changes in biomass of stoichiometrically distinctive organisms can lead to subsequent changes in the flux and storage of elements in an ecosystem, but the overall effect of aquatic animals on nutrient dynamics also is determined by discharge and nutrient-limitation patterns in streams and rivers.
\end{abstract}

Key words: consumer-driven nutrient dynamics, remineralization, nitrogen, phosphorus, biodiversity, ecosystem function

Declines in native biodiversity in freshwater ecosystems far exceed those in most terrestrial ecosystems, and projections indicate the rate of species decline will increase (Strayer and Dudgeon 2010, Vaughn 2010). Approximately $1 / 2$ of North American freshwater mussels, $1 / 3$ of crayfishes, $1 / 4$ of amphibians, and $1 / 5$ of freshwater fishes and gastropods are considered imperiled (Ricciardi and Rasmussen 1999). Freshwater systems also are threatened by increasing introductions of nonnative species. Introductions of animals, such as Nile perch (Lates miloticus) in Lake Victoria and zebra mussels (Dreissena polymorpha) in North America, demonstrate the far-reaching effects nonnative species can have on ecosystem function (Strayer 2009). Aquatic organisms directly affect nutrient storage and cycling rates by sequestering nutrients during growth and reproduction and remineralizing nutrients via excretion and egestion (Vanni et al. 2013). Thus, changes in biodiversity via species decline or introduction may have profound effects on nutrient dynamics (Strayer 2013). Many investigators have considered how species declines or introductions influence community and ecosystem dynamics, but few have quantified how changes in species composition alter consumer-driven nutrient dynamics in freshwater ecosystems.

Animals are important pools (sinks) and sources for nutrients in aquatic ecosystems (Vanni et al. 2013), and animal excretion can be an important flux of nutrients that

E-mail addresses: ${ }^{7}$ kac98@cornell.edu; ${ }^{8}$ carlalatkinson@gmail.com; ${ }^{9}$ atrugenski@gmail.com

DOI: 10.1086/681095. Received 26 January 2014; Accepted 20 August 2014; Published online 10 March 2015.

Freshwater Science. 2015. 34(2):485-496. ㄷ 2015 by The Society for Freshwater Science. 
can influence biogeochemical dynamics in freshwater ecosystems (McIntyre et al. 2008). Translocation and transformation of nutrients by animals can enhance primary production and decomposition across ecosystems and can strongly affect community composition and ecosystem function (Vanni 2002, McIntyre et al. 2008, Rugenski et al. 2012, Atkinson et al. 2013). Remineralization effects are often associated with dominant taxa (i.e., high biomass) rather than spatiotemporal variation among individual excretion rates (Caraco et al. 1997, Vanni 2002, Small et al. 2009). Variation in nutrient availability typically depends on surface and subsurface hydrologic exchanges (Dent et al. 2001) and spatial variation in microbial and algal activity (Malard et al. 2002), but excretion by animals may generate heterogeneity in nutrient availability and play an important role in nutrient cycling in fresh waters (e.g., Vanni 2002, McIntyre et al. 2008, Small et al. 2009, Capps and Flecker 2013a, b).

Most studies of consumer-driven nutrient dynamics have been focused solely on effects of organisms on nutrient remineralization (Sereda et al. 2008, Capps and Flecker 2013b), but consumers also may be important nutrient sinks in fresh waters (Kitchell et al. 1975, Strayer 2013). Animal tissue is rich in $\mathrm{N}$ and $\mathrm{P}$, elements that are important regulators of rates of primary production and decomposition in fresh waters (Sterner and Elser 2002). Moreover, animals can constitute a large amount of biomass in fresh waters and can be found in high population densities (McIntyre and Flecker 2010, Rugenski et al. 2012, Atkinson et al. 2013, Capps and Flecker 2013b). N and P are unavailable to primary producers while stored in animal tissues. Thus, freshwater animals may be a biological sink for nutrients. At the ecosystem-level, animals can function as nutrient sinks when: 1) population biomass increases, 2) emigration rates exceed immigration rates, and 3) nutrients in dead individuals are sequestered in a recalcitrant form and are unavailable to other organisms (Vanni et al. 2013).

Consumer-driven nutrient dynamics are thought to be taxon specific (Vanni 2002, McIntyre et al. 2007) and influenced by biotic and abiotic characteristics of the environment (Benstead et al. 2010, El-Sabaawi et al. 2012). Species-specific traits, such as trophic ecology, influence the rate at which freshwater organisms store and remineralize nutrients (Vanni et al. 2002). Ecological stoichiometry (ES) - the study of the balance of elements in ecological processes-considers how organisms affect and are affected by the availability of elements in ecosystems (Sterner and Elser 2002). Ecological stoichiometry predicts that biogeochemical cycles of different elements are interdependent because the organisms that drive these cycles require fixed ratios of nutrients (Sterner and Elser 2002, Elser et al. 2007). Moreover, ES predicts that organisms with high dietary requirements for an element will selectively retain that element relative to other elements (Elser and Urabe 1999, Elser et al. 2000). Therefore, an animal with low tissue N:P requirements should excrete less $\mathrm{P}$ relative to an animal with high tissue N:P and should produce waste with higher N:P. Freshwater ecosystems often are limited by $\mathrm{P}$ and $\mathrm{N}$. Thus, the ratio at which animals store and excrete nutrients is potentially important in determining the relative degree of $\mathrm{N}$ vs $\mathrm{P}$ limitation and the species composition of primary producers (Sterner and Elser 2002, Atkinson et al. 2013). According to ES predictions, organisms have the potential to influence biogeochemical processes significantly, especially when significant changes in species biomass occur, when organisms that are stoichiometrically unique are added to or lost from a system, and when the affected systems are nutrient limited (McIntyre et al. 2008, Benstead et al. 2010, Capps and Flecker 2013a, Vanni et al. 2013).

Abiotic characteristics, such as ambient nutrient chemistry, nutrient-limitation patterns, and stream discharge, also can influence the role of consumers in nutrient dynamics (Benstead et al. 2010, Small et al. 2011). For example, Benstead et al. (2010) found that seasonal changes in ambient nutrient concentrations and discharge were responsible for variability in contributions of shrimp excretion to in-stream chemistry. McIntyre et al. (2007) and Small et al. (2011) demonstrated that nutrient recycling by a single species can meet most of the in-stream nutrient demand in nutrient-limited streams. Consequently, anthropogenic activities affecting physical and chemical characteristics of fresh waters may play an important role in determining the functional role of consumers in nutrient dynamics.

Increasing rates of species extinction and invasion in fresh waters have created challenges for scientists and natural resource managers who must be able to predict the influence of the addition or loss of a single species or faunal group on overall nutrient dynamics to preserve ecosystem function. Few investigators have simultaneously quantified the role of freshwater organisms as both sources and sinks of nutrients (but see Kraft 1992, Sereda et al. 2008, Vanni et al. 2013). Comparisons of the effects of species addition and loss on nutrient dynamics across taxonomic groups and among freshwater systems require the use of standardized metrics across multiple taxa and geographic areas and consideration of both storage and remineralization. Compilation of this information will enable examination of broad-scale patterns to help determine the importance of organisms for freshwater nutrient dynamics.

Our goal was to compare the effects of 3 primary consumers (nonnative armored catfish, native mussels, and native tadpoles) on nutrient dynamics in streams. We examined interactions among organismal stoichiometry and biomass, nutrient storage and remineralization rates, and stream discharge. We considered changes in nutrient dynamics in response to the loss of native species or the 
addition of a nonnative invader to gain a better understanding of organism-specific effects on nutrient dynamics among freshwater ecosystems. We predicted that changes in biomass after invasion or decline would have the greatest effect on nutrient remineralization and storage rates in the study sites. We also hypothesized that taxon body stoichiometry would influence storage and remineralization patterns, especially if the species that were added to or lost from the system were stoichiometrically different from other organisms. Last, we posited that stream discharge would play an important role in the overall impact of species addition or decline on nutrient dynamics, where change in species abundance and diversity would have larger effects in streams with lower discharge.

\section{METHODS}

We integrated work done between 2008 and 2012 for projects examining taxonomically distinct groups of primary consumers (tadpoles, mussels, and fishes). We chose these 3 groups because some fishes, mussels, and amphibians are among the most notorious invasive species, whereas the groups as a whole are among the most globally threatened and endangered organisms (Ricciardi and Rasmussen 1999, Strayer 2010, Strayer and Dudgeon 2010).

\section{Study sites and organisms}

Armored catfish (Siluriformes:Loricariidae) were studied in the Chacamax River (lat $17^{\circ} 29^{\prime} \mathrm{N}$, long $91^{\circ} 58^{\prime} \mathrm{W}$ ), Chiapas, Mexico, during the dry season (March-May) in 2008-2010 (Table 1). Loricariids are native to Central and South America (Weber 1991, Nico and Martin 2001), but because of their popularity in the pet trade, they have been introduced into freshwater systems globally (Capps et al.
2011). Loricariids are P-rich relative to most fish families because of their body armor (Hood et al. 2005). Loricariid density was $2.3 \pm 3.4 / \mathrm{m}^{2}$ (mean $\pm \mathrm{SD}$ ) and areal biomass was $225 \pm 45 \mathrm{~g} / \mathrm{m}^{2}$ (mean $\pm \mathrm{SD}$ ), 2 orders of magnitude greater than native fish biomass in the study reach in 2010 (Capps and Flecker 2013a).

Freshwater mussels (Bivalvia:Unionidae) were studied in the Little River, Oklahoma, south central USA (lat $34^{\circ}$ $43^{\prime} \mathrm{N}$, long $\left.95^{\circ} 18^{\prime} \mathrm{W}\right)$. Mussel beds at this location are diverse and dense, and species composition changes longitudinally along the river (Atkinson et al. 2012). Mussels at this site support primary and secondary production (Vaughn and Spooner 2006, Spooner and Vaughn 2009; Table 1). A severe drought in 2011 resulted in changes in some areas of the river from continuous flow to shallow, isolated pools where water temperatures sometimes were $>40^{\circ} \mathrm{C}$ and caused an immediate, catastrophic loss of mussels. Human alteration of stream flow coupled with hotter temperatures and reduced precipitation is predicted to continue threatening freshwater habitats in this region (Vaughn and Julian 2013).

Tadpoles were studied in the dry season (DecemberApril) in four $2^{\text {nd }}$-order streams $(2$ pre- and 2 postamphibian decline) in Panamá, Central America. Tadpole biomass at postdecline sites had decreased $98 \%$ after a chytrid disease wave (Whiles et al. 2013). The predecline sites were in the Chucanti Nature Preserve (lat $8^{\circ} 85^{\prime} \mathrm{N}$, long $78^{\circ} 48^{\prime} \mathrm{W}$ ) and Cana National Park. The postdecline sites were Río Chorro in Reserva Forestal Fortuna (lat $8^{\circ}$ $42^{\prime} \mathrm{N}$, long $82^{\circ} 14^{\prime} \mathrm{W}$ ) and Río Guabal in Parque Nacional Omar Torrijos Herrera (lat $8^{\circ} 40^{\prime} \mathrm{N}$, long $82^{\circ} 35^{\prime} \mathrm{W}$ ). Amphibian populations in Río Chorro declined in 1996, and during our study the stream had small $\left(\sim 1.2\right.$ tadpoles $\left./ \mathrm{m}^{2}\right)$ remnant populations of tadpoles of the genera Lithobates,

Table 1. Study site and taxon characteristics. Temp = temperature, SRP = soluble reactive P, NA = not available.

\begin{tabular}{|c|c|c|c|c|c|c|c|c|c|c|c|c|c|c|c|c|}
\hline \multirow{3}{*}{$\begin{array}{l}\text { Study } \\
\text { region }\end{array}$} & \multirow[b]{3}{*}{ Years } & \multirow[b]{3}{*}{ Change } & \multicolumn{4}{|c|}{ Taxon information } & \multirow{2}{*}{\multicolumn{3}{|c|}{$\begin{array}{c}\begin{array}{c}\text { Physical } \\
\text { characteristics }\end{array} \\
\begin{array}{c}\text { Discharge } \\
(\mathrm{L} / \mathrm{s})\end{array}\end{array}$}} & \multicolumn{7}{|c|}{ Mean values of chemical characteristics } \\
\hline & & & \multirow{2}{*}{$\begin{array}{l}\text { Taxonomic } \\
\text { group }\end{array}$} & \multirow{2}{*}{$\begin{array}{c}\text { No. } \\
\text { species }\end{array}$} & \multicolumn{2}{|c|}{$\begin{array}{c}\text { Biomass } \\
\left(\mathrm{g} / \mathrm{m}^{2}\right)\end{array}$} & & & & \multicolumn{2}{|c|}{$\begin{array}{c}\text { SRP } \\
(\mu \mathrm{g} / \mathrm{L})\end{array}$} & \multicolumn{2}{|c|}{$\begin{array}{c}\mathrm{NH}_{4}-\mathrm{N} \\
(\mu \mathrm{g} / \mathrm{L})\end{array}$} & \multirow{2}{*}{$\begin{array}{c}\mathrm{NO}_{3}-\mathrm{N} \\
(\mu \mathrm{g} / \mathrm{L})\end{array}$} & \multicolumn{2}{|c|}{$\begin{array}{l}\text { Limiting } \\
\text { resource }\end{array}$} \\
\hline & & & & & Pre & Post & $\begin{array}{l}\text { Temp } \\
\left({ }^{\circ} \mathrm{C}\right)\end{array}$ & Pre & Post & Pre & Post & Pre & Post & & Pre & Post \\
\hline Panama & $\begin{array}{l}2009- \\
2011\end{array}$ & Decline & Ranidae & 20 & 1.3 & 0.03 & 20 & 55 & 55 & 25 & 7 & 30 & 20 & NA & Light & Light \\
\hline $\begin{array}{l}\text { Oklahoma, } \\
\text { USA }\end{array}$ & $\begin{array}{l}2010- \\
2012\end{array}$ & Decline & Unionidae & $6^{\mathrm{b}}$ & 2040 & 1210 & 29 & 500 & $\sim 0$ & 27.5 & NA & NA & 13.5 & 19.8 & NP & $\mathrm{N}$ \\
\hline Mexico & $\begin{array}{l}2008- \\
2010\end{array}$ & Invasion & Loricariidae & 1 & $1^{\mathrm{a}}$ & 230 & 25 & 1600 & 1600 & NA & $<2$ & NA & 10 & 353 & $\mathrm{P}$ & $\mathrm{P}$ \\
\hline
\end{tabular}

\footnotetext{
a 2010 values

${ }^{\mathrm{b}}$ Data on tissue stoichiometry and excretion for the 6 most common species, however 12 species were found during quadrat sampling at this site. Average values are used for these less common species.
} 
Smilisca, and Colostethus. Predecline, Río Guabal had $\sim 20$ species of riparian anurans at densities of $\sim 50$ tadpoles $/ \mathrm{m}^{2}$ (Whiles et al. 2006). During our study, tadpole densities were $<0.1 / \mathrm{m}^{2}$.

\section{Storage, remineralization, and volumetric excretion estimates}

We estimated the biomass of each taxon in its respective habitat and collected individuals for remineralization trials and body-tissue-chemistry analysis. Methods used to estimate pre- and postdecline or invasion effects on organismal biomass varied among study sites and organisms.

Loricariid and native fish biomass was estimated with snorkeling methods modified from Thurow (1994) and were outlined by Capps and Flecker (2013a). Loricariid biomass accrual rates were estimated as the change in biomass between 2008 and 2010. We did not have biomass estimates for the native fish population in 2008, but their biomass was $\sim 1.4 \mathrm{~g} / \mathrm{m}^{2}$ in 2010 (Capps and Flecker 2013a). Thus, we assumed the biomass accumulation of native fishes was 2 orders of magnitude less than the loricariids. This estimate is conservative because it assumes that native fish biomass continued to increase with increasing biomass of loricariids.

Mussels were sampled quantitatively in a large mussel bed $\left(3150 \mathrm{~m}^{2}\right)$ in June 2010 (predrought) and June 2012 (postdrought). Density and biomass (using length-mass regressions) were estimated with previously described methods (Vaughn et al. 2004, Atkinson et al. 2012, Spooner et al. 2012). These data were combined with density data to scale biomass from quadrat to reach scale for 2010 and 2012 (Vaughn and Spooner 2006). We used previously published species-specific growth rates (Haag and Rypel 2011) to estimate changes in biomass accrual. Tadpole biomass and length-mass regressions were estimated with methods described by Colon-Gaud et al. (2010). Change in tadpole biomass accrual was estimated by comparing biomass in the pre- and postdecline sites.

Concentrations of body $\mathrm{N}$ and $\mathrm{P}$ were estimated by drying and grinding whole individual mussels (shells were ground separately from soft tissue), whole individual loricariids, and tadpole tails. Samples were dried to a constant mass at 45 to $50^{\circ} \mathrm{C}$ for $\geq 48 \mathrm{~h}$, weighed, and ground to a fine powder. For $\mathrm{N}, \sim 2$ to $8 \mathrm{mg}$ of dried material were analyzed. Tadpoles were analyzed on an OI Analytical Flow Solution IV analyzer (OI Analytical, College Station, Texas), mussels were analyzed on a Finnigan Delta Plus mass spectrophotometer (Thermo-Finnigan, Bremen, Germany) at the University of Georgia Analytical Laboratory, and catfish were analyzed on an Elementar Vario EL III elemental analyzer (Elementar, Hanau, Germany) at Cornell University. For particulate $\mathrm{P}$ analysis, subsamples of $\sim 1$ to $4 \mathrm{mg}$ of material were combusted at $500^{\circ} \mathrm{C}$, digested with $1 \mathrm{~N} \mathrm{HCl}$ for $2 \mathrm{~h}$, and the digested solution was ana- lyzed spectrophotometrically using standard colorimetric methods (APHA 1998). Changes in N and P areal storage were calculated as the change in the product of the areal biomass accrual estimates and \% element in the tissue samples.

Areal excretion estimates were calculated as the product of areal biomass and the mass-based excretion rates for each species following McIntyre et al. (2008) and Vanni et al. (2002). Briefly, remineralization rates were estimated (mussels and tadpoles: /g dry mass; loricariids: /g wet mass) based on the mean difference in dissolved $\mathrm{N}$ or $\mathrm{P}$ concentrations between volumes of water incubated with and without the study organism. For mussels, the calculations included only dry tissue mass and did not include shell mass because of the high variability in shell mass within and across species. At the end of the incubation period, water samples were filtered and preserved for analysis or were analyzed in the field (mussels: samples were acidified and analyzed at the R. S. Kerr Laboratory [US Environmental Protection Agency, Ada, Oklahoma]; loricariids and tadpoles: $\mathrm{P}$ samples were acidified, shipped to the USA, and analyzed at the Cary Institute of Ecosystem Studies [Millbrook, New York]). $\mathrm{NH}_{4}{ }^{+}$samples were refrigerated and analyzed in the field using the fluorometric methods outlined by Taylor et al. (2007). Soluble reactive P (SRP) values for each of the study organisms were estimated using standard colorimetric methods (APHA 1998).

To estimate the net effects of the additions or declines of animal populations, we estimated net remineralization rates and changes in volumetric excretion $\left(\mathrm{E}_{\mathrm{V}}\right)$. We estimated remineralization rates for both $\mathrm{N}\left(\mathrm{NH}_{4}-\mathrm{N}\right)$ and $\mathrm{P}$ (SRP-P) and biomass accrual rates (body $\mathrm{N}$, body $\mathrm{P}$ ) for each taxon and calculated net remineralization rates $\left(\mathrm{R}_{\mathrm{Net}}\right)$ by subtracting the elemental biomass accrual rate from the elemental remineralization rate. Thus, positive values indicate a net flux of elements into the system and negative values indicate net storage of an element in body tissues (Capps and Flecker 2013a). In our study, net remineralization rates did not account for the nutrient fluxes from egestion, decomposing tissues, predation, or parasitism. Moreover, $R_{\text {Net }}$ is a proxy for the potential role of animals as sinks, and not a truly quantitative measurement of sink strength. $E_{V}$ is the mean addition of elements remineralized by an animal into the water column as it moves along a stream reach (McIntyre et al. 2008). We used methods modified from Benstead et al. (2010) and estimated $E_{V}$ as the product of the areal excretion rate ( $\mu$ mol nutrient $\mathrm{m}^{-2} \mathrm{~h}^{-1}$ ), the area of a 100-m reach of stream $\left(\mathrm{m}^{2}\right)$, and the travel time through stream reach $(\mathrm{h})$ divided by the volume of water in the given reach $\left(\mathrm{m}^{3}\right)$.

Catfish calculations were made by comparing native fish remineralization rates and average body nutrient content to armored catfish remineralization rates and average body nutrient content. Mussel calculations were made by 
comparing the mussel remineralization and body nutrient content before and after mussel declines. Tadpole calculations were made by comparing remineralization and body nutrient content stored in tadpoles from streams with and without chytrid infection.

\section{RESULTS}

Total biomass changed after species invasion or species decline in all 3 systems, but the change was most pronounced in the freshwater mussel community (biomass decline $>2000 \mathrm{~kg} / 100 \mathrm{~m}$ of stream) (Fig. 1A). However, the percentage of biomass change within a site was greater for catfish (16,000\%) and tadpoles (97\%) than mussels (41\%). Changes in species composition had large effects on tissue

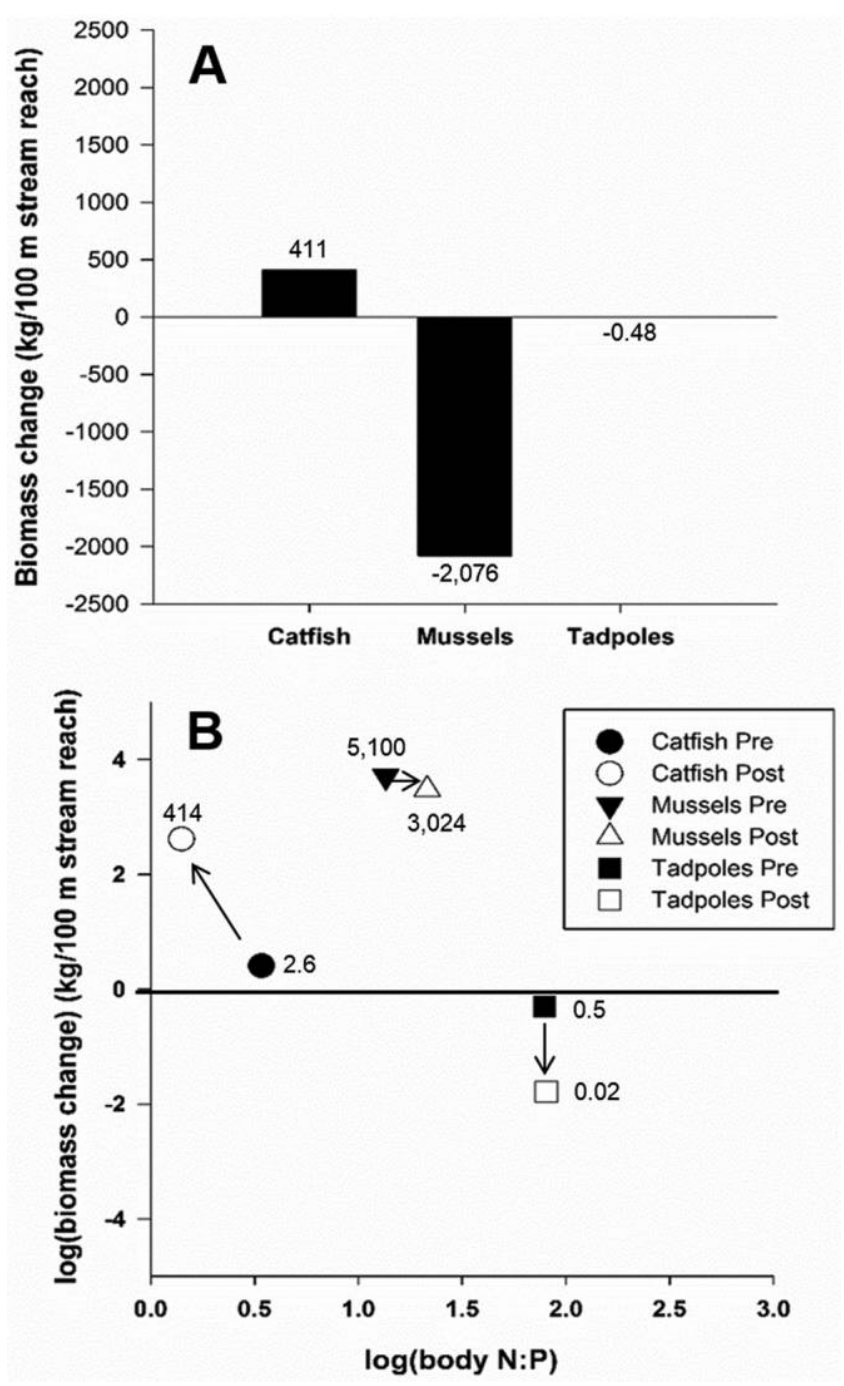

Figure 1. Biomass change after armored catfish invasion and tadpole and mussel decline (A) and biomass before and after species addition or decline vs body N:P of catfish, mussels, and tadpoles (B). Arrows indicate the direction of the change after invasion or decline.
N:P ratios of the Chacamax River fish assemblage (59\% reduction) and Little River mussel communities (58\% increase), but had little effect on $\mathrm{N}: \mathrm{P}$ ratios of the Panamanian tadpole community (1.6\%; Fig. 1B).

Estimated $\mathrm{N}$ excretion rates for the 3 study taxa fell within published values for other aquatic consumers (Hall et al. 2003, McIntyre et al. 2008, Benstead et al. 2010, Small et al. 2011), but mussels and tadpoles had higher $P$ areal excretion rates than published values for other taxa (McIntyre et al. 2008, Benstead et al. 2010, Small et al. 2011). Changes in $N$ and $P$ remineralization and biomass accrual rates after catfish invasion in the Chacamax River were several orders of magnitude larger than for mussel and tadpole communities in the Little River and Panama after native species decline (Fig. 2A, B). Nevertheless, both mussel and tadpole declines had large effects on remineralization and biomass accrual of $\mathrm{N}$ and $\mathrm{P}$, and exhibited reductions of $\sim 30$ and $100 \%$, respectively.

Net nutrient remineralization was altered in all 3 cases (Fig. 3A, B). As predicted by ES, the P-rich taxa (native mussels and nonnative catfish) selectively retained $\mathrm{P}$ relative to $\mathrm{N}$ and were responsible for larger net fluxes of $\mathrm{N}$ into their respective systems relative to the $\mathrm{N}$-rich tadpoles (Fig. 3A, B). After mussel decline, the increase in $\mathrm{R}_{\mathrm{Net}}$ of $\mathrm{P}(55 \%)$ was greater than the concurrent increase of $\mathrm{N}$ (41\%), indicating less $\mathrm{P}$ was being stored in mussel tissues and shells relative to $\mathrm{N}$. The high biomass of invading, P-rich catfish had a similar effect, wherein the catfish had high net $\mathrm{N}$ remineralization rates, but converted the fish community into a net $\mathrm{P}$ sink (at least until the population growth stabilizes; Fig. $3 B$ ). The change in $R_{N e t}$ in Panamanian streams was driven by declines in $R_{\text {Net }}$ $\mathrm{N}$ relative to $R_{\text {Net }} \mathrm{P}$ by the $\mathrm{N}$-rich tadpole community (Fig. 3A, B). Changes in the N:P of $\mathrm{R}_{\mathrm{Net}}$ for catfish and tadpoles agreed with ES predictions. $\mathrm{N}: \mathrm{P}$ of $\mathrm{R}_{\mathrm{Net}}$ increased from 44 to 147 for P-rich catfish and decreased from 4 to 1 for N-rich tadpoles.

Change in $E_{V}$ indicated that ecosystem size was an important determinant of whether species addition or decline altered the flux of nutrients in lotic ecosystems (Fig. 4A). The change in tadpole biomass (Fig. 1A) and $R_{\text {Net }}$ suggest tadpole decline may not have substantially affected nutrient dynamics, but the $\mathrm{E}_{\mathrm{V}}$ estimates indicated tadpole excretion might be an important flux of nutrients in Panamanian streams (Fig. 4A). A similar pattern was seen in the mussel community (Figs 2A, B, 4A). Invading catfish had substantial effects on remineralization and storage rates of both $\mathrm{N}$ and $\mathrm{P}$, but their effect on $\mathrm{E}_{\mathrm{V}}$ was orders of magnitude smaller than effects of amphibian and mussel decline in their respective systems (Figs 2A, B, $4 \mathrm{~A})$. Together, evidence from all taxa and sites suggested that changes in biomass and ecosystem size (in these studies, fluctuating discharge) were not the only important factors influencing the contribution of remineralized ele- 

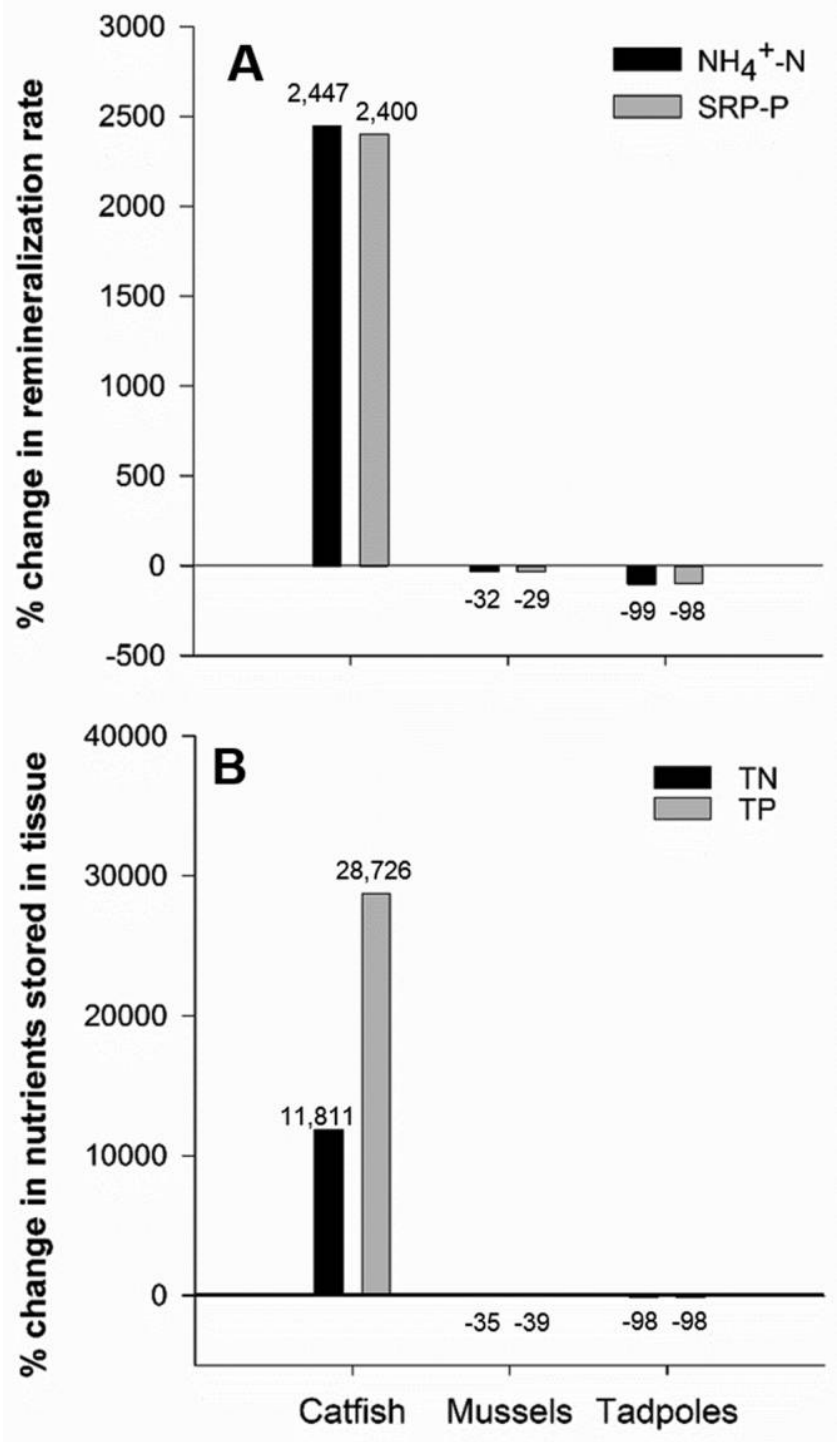

Figure 2. Percent change in $\mathrm{NH}_{4}-\mathrm{N}$ and soluble reactive $\mathrm{P}$ (SRP) remineralization rates $(\mathrm{A})$ and in total $\mathrm{N}(\mathrm{TN})$ and total $\mathrm{P}$ (TP) stored in body tissues (B) after species addition (catfish) or decline (mussels, tadpoles).

ments to the water column by the study taxa. Speciesspecific stoichiometry influenced $\mathrm{E}_{\mathrm{V}}$ and $\mathrm{R}_{\mathrm{Net}}$ (Fig. 4A, B).

\section{DISCUSSION}

\section{Effects of invasions and declines of consumers} on nutrient dynamics

Many researchers have investigated the functional roles of animals in freshwater nutrient dynamics (e.g., McIntyre et al. 2008, Benstead et al. 2010, Atkinson et al. 2013, Capps and Flecker 2013a, Whiles et al. 2013), but we are the first to compare these roles across species and systems in the context of species declines and invasions. Our results demonstrate that additions and declines of disparate species can have large, measureable effects on nutrient accrual and remineralization rates in streams of various sizes. Catastrophic decline of species resulted in major declines, and invasion resulted in substantial increases in nutrient remineralization rates and storage. Collectively, the cases of invasion and loss we presented highlight some of the characteristics of species with the potential to strongly influence nutrient dynamics and the biotic and abiotic characteristics of ecosystems that would be make them susceptible to biogeochemical change in response to species invasion and loss. The magnitude and ecological significance of changes in nutrient dynamics depend on a combination of biotic and abiotic factors including assem-

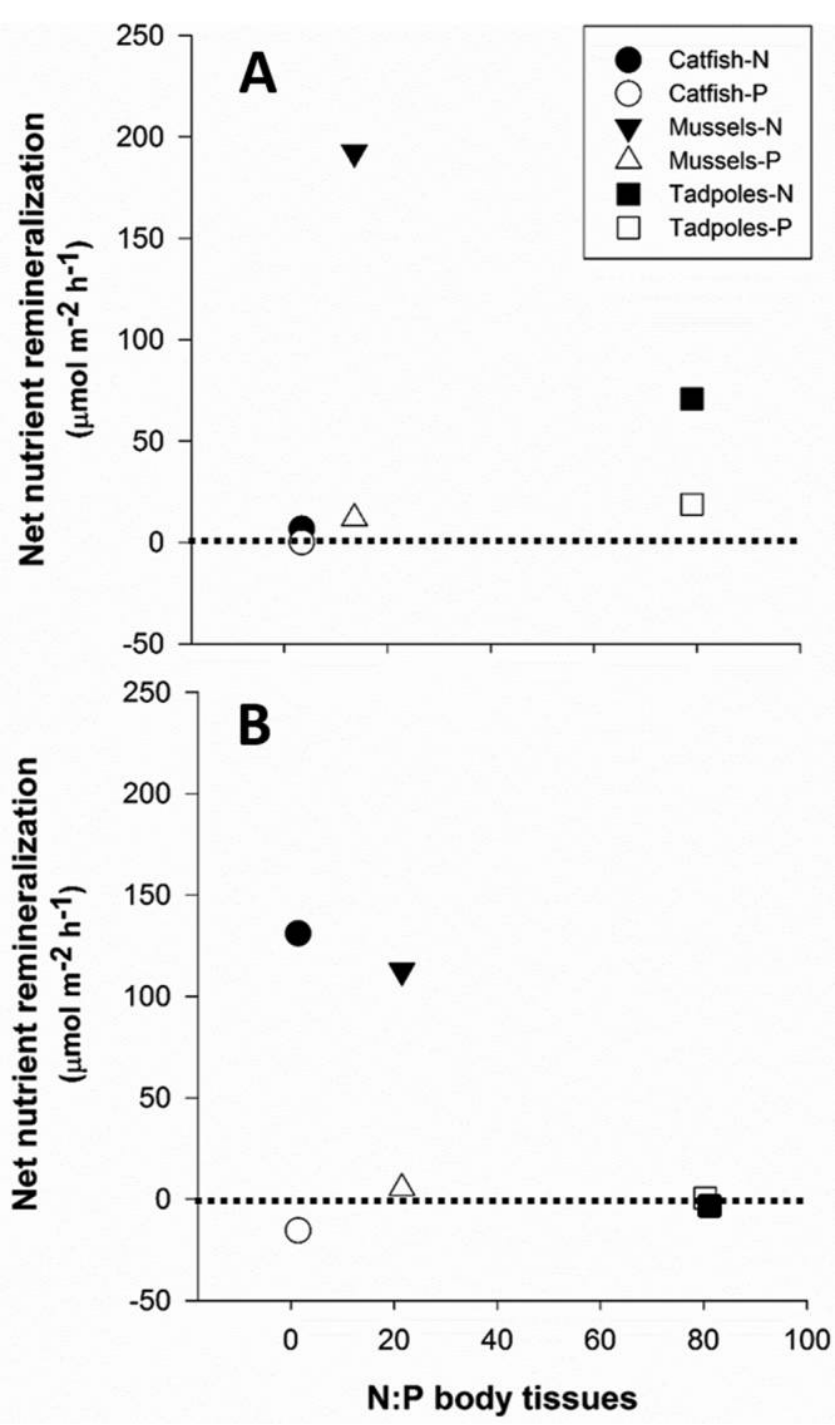

Figure 3. Net nutrient remineralization $\left(\mathrm{R}_{\mathrm{Net}}\right)$ by organisms before (A) or after (B) species addition (catfish) or species decline (mussels, tadpoles). Values were obtained by subtracting areal nutrient storage rates from areal nutrient remineralization rates. Positive values indicate net nutrient remineralization and negative values indicate net nutrient storage for catfish, tadpoles, and mussels. 

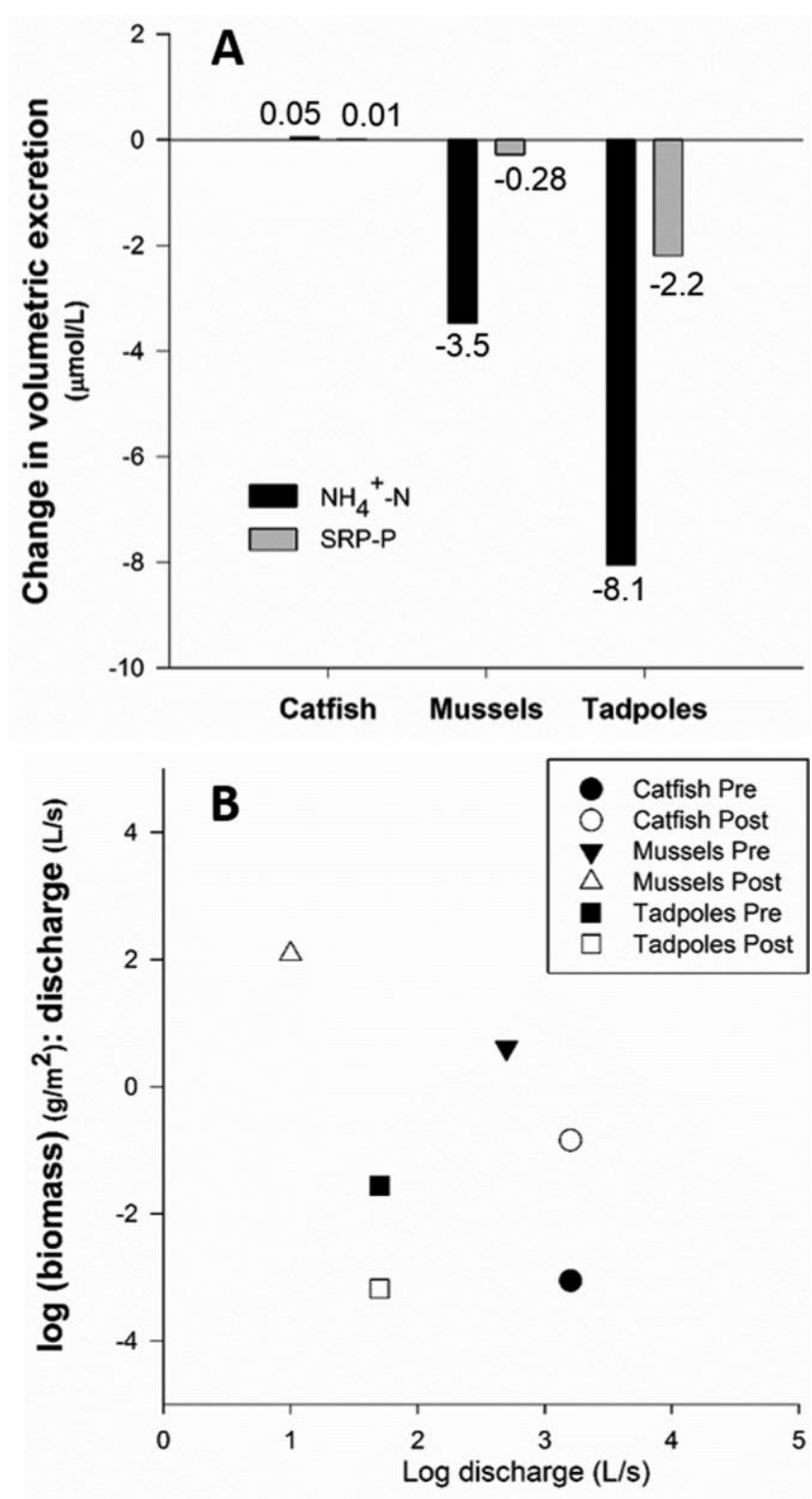

Figure 4. Change in volumetric excretion $\left(E_{V}\right)$, the mean addition of elements remineralized by animals into the water column as it moves along a 100-m stream reach (A) and the relationship between the ratio of log-transformed biomass to discharge and log-transformed discharge (B) after species invasion or species decline.

blage diversity and biomass, consumer stoichiometry, and discharge.

Our results provide support for the idea that stoichiometric characteristics of aquatic organisms can be used to predict changes in nutrient availability in the wake of species invasion or decline (Small et al. 2009, Atkinson et al. 2013, Capps and Flecker 2013a). Changes in nutrient dynamics can be nutrient specific, and organisms may influence $\mathrm{R}_{\mathrm{Net}}$ of $\mathrm{N}$ and $\mathrm{P}$ differently. In fish assemblages, $\mathrm{P}$ excretion rates are heavily influenced by body P content, where species with greater body P remineralize P at lower rates (McIntyre et al. 2007, Small et al. 2011). In our study, invading catfish and declining mussel populations had low body N:P, which led to a corresponding increase (catfish invasion) and decrease (mussel decline) in the $\mathrm{N}: \mathrm{P}$ of $\mathrm{R}_{\mathrm{Net}}$ in the affected systems.

Organismal contributions to nutrient dynamics are influenced by the relative biomass of the focal taxa within a given community and taxon-specific nutrient remineralization and accrual rates (Vanni et al. 2002, McIntyre et al. 2007, Benstead et al. 2010, Capps and Flecker 2013a). All of our study organisms, including the N-rich tadpoles, were net remineralizers of $\mathrm{N}$. However, high densities of armored catfish functioned as net P sinks, and N-rich tadpoles functioned as net remineralizers of $\mathrm{P}$. The difference in effects on remineralization among taxa may have been caused, in part, by $\mathrm{N}$ availability or the physiological constraints of processing different elements. Mussel $R_{N e t} P$ was low pre- and postdecline, a result suggesting their effect on $\mathrm{P}$ availability should be investigated further. More work needs to be done to integrate physiological ecology, stoichiometry, and biogeochemistry.

These 3 case studies suggest that changes in biogeochemical cycling should be expected when a large biomass of stoichiometrically unique organisms is added to or lost from a system, but these changes may depend on the taxon lost or gained. Increases in the biomass of armored catfish influenced the stoichiometry of $R_{N e t}$, but a similar shift was not evident with tadpole or mussel loss, which caused smaller shifts in the stoichiometry of the dominant species (by biomass). The total change in biomass after tadpole loss and armored catfish invasion was small relative to the thousands of kilograms of biomass lost in the mussel population, but the resulting biomasses in the tadpole and armored catfish systems were orders of magnitude different than the initial biomasses.

Aquatic organisms have the ability to function as keystone nutrient remineralizers by having disproportionately large effects on nutrient remineralization relative to their biomass (McIntyre et al. 2007, Small et al. 2011). In the 3 case studies, biomass changes did not always predict the subsequent changes to ecosystem-level nutrient dynamics, and some organisms appeared to have proportionally larger effects on nutrient dynamics than their biomass would indicate (Fig. 4A, B). We found large changes in volumetric excretion of $\mathrm{N}$ and $\mathrm{P}$ after tadpole decline even though change in biomass after tadpole loss was exceptionally small relative to changes in mussel and fish biomass. Whiles et al. (2013) found that tadpoles may supply up to $40 \%$ of nutrient demand to these systems, and the loss of tadpoles decreased nutrient uptake and efficiency of nutrient cycling. A similar pattern was seen in low-P streams in Costa Rica, where the fish Astyanax aeneus, made up $<20 \%$ of the to- 
tal biomass of the abundant fishes, but remineralized $90 \%$ of the P supplied by the fish community and supplied 90\% of P demand (Small et al. 2011).

\section{Consumers as nutrient sources and sinks}

Most studies of consumer-driven nutrient dynamics have been limited to the effects of organisms on nutrient remineralization (but see Sereda et al. 2008, Capps and Flecker 2013b, Vanni et al. 2013), but consumers also may function as nutrient sinks (Kitchell et al. 1975, Strayer 2013). Nutrient-sink dynamics were not measured directly in any of the 3 case studies, but we found evidence suggesting taxon- and nutrient-specific sink dynamics (Fig. 3A, B). Here, we present likely scenarios for nutrient-sink dynamics in the 3 systems.

The loss of mussels from the Little River probably resulted in an immediate loss of the $\mathrm{N}$ stored in mussel soft tissues via decomposition. The $\mathrm{P}$ in P-rich shells also may have declined as mussel beds were lost from the system, but the rate at which $P$ was remineralized from shell tissue of dead mussels probably was much slower than the rate at which $\mathrm{N}$ was remineralized from soft tissue. Thus, decomposing mussels may have initially been a large source of $\mathrm{N}$, but remained a sink for $\mathrm{P}$.

Explosive growth of P-rich catfish might have had similar effects in the Chacamax River. High densities of excreting catfish generate biogeochemical hotspots of both $\mathrm{N}$ and P (Capps and Flecker 2013b), but catfish also accrue $\mathrm{N}$ and $\mathrm{P}$ in biomass (Capps and Flecker 2013a). Biomass accrual and remineralization dynamics after invasion were driven by the increase in catfish biomass relative to native fish biomass (Capps and Flecker 2013a). Stoichiometrically distinct fishes converted the river from a system in which fishes may not have had a strong, direct effect on nutrient dynamics to a system in which the fish community was a substantial source of $\mathrm{N}$ and a sink of $\mathrm{P}$ (Fig. 3A, B). The loss of tadpoles and mussels did not alter the stoichiometry of $R_{\mathrm{Net}}$ in the affected system as strongly as the invasion of catfish did (Fig. 3A, B). The communities that remained after the losses of tadpoles and mussels were still dominated by organisms of similar stoichiometries (Panama: macroinvertebrates, Rugenski 2013; Oklahoma: other mussel species, Atkinson et al. 2014) so $R_{\mathrm{Net}}$ changed relatively little.

Prior to decline, tadpoles probably were sinks of both $\mathrm{N}$ and $\mathrm{P}$ (Vanni et al. 2013). Healthy populations of growing tadpoles increase in biomass through time (assuming predators incorporated tadpole tissue into other living tissue), and the emerging juveniles would function as a sink when they emigrated from streams after metamorphosis. Thus, the catastrophic decline of tadpoles eliminated a potentially important nutrient sink and fractured an important nutrient-transport linkage between freshwater ecosystems and the terrestrial environment.

\section{Unanswered questions and future research needs}

Trophic position influences how organisms affect ecosystem-level nutrient dynamics. When low-trophicposition organisms, such as the 3 primary consumers in our study, are added to or lost from an ecosystem, great potential exists for alteration of basal food resources (Gido and Franssen 2007, Gruner et al. 2008, Rugenski et al. 2012) and subsequent modification of algal and microbial stoichiometry and nutrient uptake rates (Liess and Kahlert 2009, Whiles et al. 2013). The effects of primary consumers on the nutrient content of benthic communities can be influenced by body stoichiometry (Knoll et al. 2009). ES predicts that organisms with high requirements for an element will selectively retain that element and correspondingly reduce remineralization rates (Sterner and Elser 2002). Therefore, growth rates of nutrient-rich organisms feeding on nutrient-poor resources, including many herbivorous and detritivorous species, can be nutrient limited (Hood et al. 2005), and those consumers may have strong, direct effects on nutrient dynamics (Capps and Flecker 2013a). Effects of species addition or decline on nutrient dynamics may be intensified in nutrient-limited systems where primary consumers regulate algal growth and nutrientlimitation patterns (Flecker et al. 2002, Atkinson et al. 2013) and may be trivial in highly eutrophied systems (Wilson and Xenopoulos 2011). However, this pattern may not always be the case, and more work is needed that experimentally tests the effects of nutrient limitation, species traits, and the population dynamics of invasive, threatened and endangered species on consumer-driven nutrient dynamics at multiple spatial scales.

Abiotic factors, such as ecosystem size and ambient chemistry, also can affect the significance of consumer contribution to ecosystem nutrient dynamics (Benstead et al. 2010). Stream discharge influenced the effect of an individual species or species group on nutrient dynamics at our 3 study sites. The volume of water moving through each system was variable, and this variability led to large differences in $E_{v}$ across systems. The greatest changes in biomass occurred in the catfish and mussel systems, but the largest decline in $\mathrm{N}$ and $\mathrm{P}$ volumetric excretion occurred in the tadpole system (Fig. 4A, B). Mussel decline was driven by drought that severely reduced the volume of water moving through the stream. Thus, the mussel system experienced simultaneous decreases in discharge and the ratio of biomass to discharge. Had the discharge remained unchanged and the mussel decline been driven by disease (as with the tadpoles), the negative change in $E_{v}$ would have been much greater. All of these studies were conducted during relatively dry periods. Consumerdriven nutrient dynamics may be less important during wetter periods, when discharge and terrestrial runoff are higher. Future investigators should consider how seasonal changes and other aspects of temporal variability influence the import of consumers on biogeochemical cycling. 
The addition or decline of suites of species may have a much larger effect on consumer-driven nutrient dynamics than the change in abundance of a single species. Other investigators have documented the pivotal role of a single species in mediating biogeochemical processes in streams (e.g., Flecker 1996, McIntyre et al. 2007) and questioned the idea of functional redundancy among freshwater organisms (Whiles et al. 2013). In our study, the effects of invasion of a large biomass of stoichiometrically unique catfish, a single species, supports the idea of pivotal species. However, we assert that the catastrophic loss of an entire suite of species with relatively similar trophic ecologies and body stoichiometries within a system would have a greater effect on nutrient dynamics than would be realized by the loss of a single species in the system, as was the case in the tadpole and mussel studies. Future investigators attempting to integrate consumer-driven nutrient dynamics with species invasion and loss should strive to examine changes in community-level nutrient dynamics across disparate taxa.

The 3 primary consumers we studied could have modified nutrient-uptake rates and nutrient-limitation patterns. For example, fishes can reduce algal biomass and modify the response of primary producers to the addition of nutrients (Flecker et al. 2002). Our study sites had moderate-tolow ambient nutrient concentrations, and primary producers responded to nutrient amendments, indicating nutrient limitation in the mussel and catfish systems. In Panamanian streams affected by chytrid infection, tadpole loss is concomitant with an increase in nutrient uptake length (Whiles et al. 2013). Our results suggest that continued loss of mussels from Oklahoma streams may cause a switch from colimitation by $\mathrm{N}$ and $\mathrm{P}$ to $\mathrm{N}$-limitation with consequent changes in periphyton assemblages (Atkinson et al. 2013). In contrast, catfish invasion may enhance P-limitation as indicated by their high $\mathrm{N}$ remineralization rates (Capps and Flecker 2013a).

Alteration of nutrient dynamics by species addition or loss could have a cascading effect (Connelly et al. 2008, Hooper et al. 2012, Whiles et al. 2013) leading to further reductions in biodiversity and processing rates. In addition to altering biogeochemical cycling (Grimm 1988, Hall et al. 2003, Atkinson et al. 2010, 2013, Capps and Flecker 2013b), consumer-driven nutrient dynamics can affect primary production (Vanni et al. 2006, Connelly et al. 2008), microbial activity, and leaf-litter decomposition rates (Rugenski et al. 2012). Hence, changes in nutrient dynamics in response to species addition or decline have the potential to influence other ecosystem processes that may lead to changes in $\mathrm{C}$ cycling, foodweb connectivity, and the abundance and diversity of other taxonomic groups.

Effects of organisms on nutrient dynamics can be heterogeneous within ecosystems because of the patchy distribution of animals and species-specific nutrient remineralization and biomass accrual patterns (McIntyre et al. 2008).
Aggregations of animals in certain habitats in aquatic ecosystems can generate biogeochemical hotspots of nutrient remineralization through excretion (McIntyre et al. 2008, Atkinson et al. 2013, Capps and Flecker 2013b). The scales at which our ecosystem-level measurements were made (mean biomass per $\mathrm{m}$ or per $100-\mathrm{m}$ reach) certainly do not convey the heterogeneous chemical environments that were created or destroyed in our study systems. $R_{\text {Net }}$ estimates for $\mathrm{P}$ for mussels and loricariids were near 0 , suggesting they may function as system-wide sinks of $\mathrm{P}$ relative to $\mathrm{N}$, but large aggregations of mussels and catfish still may generate locally important fluxes of $\mathrm{P}$ into the water column (Atkinson et al. 2013, Capps and Flecker 2013b). Therefore, one major effect of species invasion or decline on nutrient dynamics is likely to be altered patterns of nutrient heterogeneity in the water column. More work is needed to quantify changes in spatial heterogeneity in nutrient dynamics and the subsequent alterations in algal and microbial community structure (e.g., Atkinson et al. 2013).

Human alteration of fresh waters is widespread and will lead to further changes in biodiversity of aquatic ecosystems. Links between biodiversity and ecosystem function have been documented in fresh waters throughout the globe (Cardinale et al. 2002, McIntyre et al. 2007, Rugenski et al. 2012, Atkinson et al. 2013, Capps and Flecker 2013a), but predicting the effects of changing diversity on ecosystem processes is exceptionally difficult because the functional response of a system to the addition or decline of species will depend upon a combination of species- and ecosystem-specific characteristics (McIntyre et al. 2007, Strayer and Dudgeon 2010). We found that the invasion or decline of stoichiometrically distinct species at high biomass resulted in a proportionate response in nutrient accrual in biomass and cycling. These effects should be more acute in nutrient-limited ecosystems, systems experiencing the loss or addition of diverse assemblages of species or keystone nutrient remineralizers, and smaller systems undergoing relatively large shifts in the ratio of organismal biomass to discharge. We echo the sentiment of Vanni et al. (2013) that more investigators should comprehensively examine the complex ways organisms influence elemental cycling in fresh waters. We argue that use of metrics that reflect both source-sink dynamics and ecosystem size will promote comparative work that will move the study of consumer-driven nutrient dynamics forward. Loss of native biodiversity and introduction of nonnative species are ubiquitous problems threatening the functional integrity of fresh waters globally (Strayer and Dudgeon 2010, Strayer 2012). Conservation planning activities can and should strive to use metrics integrating species-specific traits, such as biomass and body stoichiometry, with ecosystem-specific traits, such as nutrient limitation and ecosystem size, to elucidate the effects of changing biodiversity on nutrient dynamics in fresh waters. 


\section{ACKNOWLEDGEMENTS}

We thank Alex Flecker, Caryn Vaughn, and Matt Whiles for their advice and support developing ideas that supported this research. We thank Robert Northington, Thomas Parr, and Caryn Vaughn and the Vaughn Lab for reviewing an early version of this manuscript. Organisms were harvested in Mexico using Mexican collection permit number DGOPA.07525.25706 .3233 , and fishes were handled using methods outlined in the Institutional Animal Care and Use Committee protocol 20060169 from Cornell University. All tadpole research complied with the current laws of the Republic of Panama, as stated in the scientific permit SE/A-40-10. All animal handling and sacrifices followed the animal care protocols established by Southern Illinois University Carbondale (Protocol 08-022). KAC's work was supported by the National Science Foundation (NSF) (DDEP grant 183-8371), Integrative Graduate Education and Research Traineeship 0221658, the Fulbright-Hays Doctoral Dissertation Research Abroad Program, and the Margaret Paul Graduate Fellowship in the Life Sciences at Cornell University. CLA's work was supported by an Environmental Protection Agency Science To Achieve Results fellowship, a Wethington Fellowship through the University of Oklahoma Graduate School, and support from the Oklahoma University biology department. AR's work was supported by the NSF grant DEB 0717741 and the Society for Freshwater Science Conservation award.

\section{LITERATURE CITED}

APHA (American Public Health Association). 1998. Standard methods for the examination of water and wastewater. 20th edition. American Public Health Association, American Water Works Association, and Water Environment Federation, Washington, DC.

$\rightarrow$ Atkinson, C. L., J. P. Julian, and C. C. Vaughn. 2012. Scaledependent longitudinal patterns in mussel communities. Freshwater Biology 57:2272-2284.

$\rightarrow$ Atkinson, C. L., J. P. Julian, and C. C. Vaughn. 2014. Species and function lost: role of drought in structuring stream communities. Biological Conservation 176:30-38.

$\rightarrow$ Atkinson, C. L., S. P. Opsahl, A. P. Covich, S. W. Golladay, and L. M. Conner. 2010. Stable isotopic signatures, tissue stoichiometry, and nutrient cycling ( $\mathrm{C}$ and $\mathrm{N}$ ) of native and invasive freshwater bivalves. Journal of the North American Benthological Society 29:496-505.

$\rightarrow$ Atkinson, C. L., C. C. Vaughn, K. J. Forshay, and J. T. Cooper. 2013. Aggregated filter-feeding consumers alter nutrient limitation: consequences for ecosystem and community dynamics. Ecology 94:1359-1369.

$\rightarrow$ Benstead, J. P., W. F. Cross, J. G. March, W. H. McDowell, A. Ramírez, and A. P. Covich. 2010. Biotic and abiotic controls on the ecosystem significance of consumer excretion in two contrasting tropical streams. Freshwater Biology 55:2047-2061.

$\rightarrow$ Capps, K. A., and A. S. Flecker. 2013a. Invasive aquarium fish transform ecosystem nutrient dynamics. Proceedings of the Royal Society of London Series B: Biological Sciences 280: 20131520.

$\rightarrow$ Capps, K. A., and A. S. Flecker. 2013b. Invasive fishes generate biogeochemical hotspots in a nutrient-limited system. PLoS ONE 8:e54093. $\rightarrow$ Capps, K. A., L. G. Nico, M. Mendoza-Carranza, W. ArevaloFrias, A. J. Ropicki, S. A. Heilpern, and R. Rodiles-Hernandez. 2011. Salinity tolerance of non-native suckermouth armoured catfish (Loricariidae: Pterygoplichthys) in south-eastern Mexico: implications for invasion and dispersal. Aquatic Conservation: Marine and Freshwater Ecosystems 21:528-540.

$\rightarrow$ Caraco, N. F., J. J. Cole, P. A. Raymond, D. L. Strayer, M. L. Pace, S. E. G. Findlay, and D. T. Fischer. 1997. Zebra mussel invasion in a large, turbid river: phytoplankton response to increased grazing. Ecology 78:588-602.

$\rightarrow$ Cardinale, B. J., M. A. Palmer, and S. L. Collins. 2002. Species diversity enhances ecosystem functioning through interspecific facilitation. Nature 415:426-429.

$\rightarrow$ Colon-Gaud, C., M. R. Whiles, R. Brenes, S. S. Kilham, K. R. Lips, C. M. Pringle, S. Connelly, and S. D. Peterson. 2010. Potential functional redundancy and resource facilitation between tadpoles and insect grazers in tropical headwater streams. Freshwater Biology 55:2077-2088.

$\rightarrow$ Connelly, S., C. M. Pringle, R. J. Bixby, R. Brenes, M. R. Whiles, K. R. Lips, S. Kilham, and A. D. Huryn. 2008. Changes in stream primary producer communities resulting from largescale catastrophic amphibian declines: can small-scale experiments predict effects of tadpole loss? Ecosystems 11:12621276.

$\rightarrow$ Dent, C. L., N. B. Grimm, and S. G. Fisher. 2001. Multiscale effects of surface-subsurface exchange on stream water nutrient concentrations. Journal of the North American Benthological Society 20:162-181.

$\rightarrow$ El-Sabaawi, R. W., E. Zandonà, T. J. Kohler, M. C. Marshall, J. M. Moslemi, J. Travis, A. López-Sepulcre, R. Ferrière, C. M. Pringle, S. A. Thomas, D. N. Reznick, and A. S. Flecker. 2012. Widespread intraspecific organismal stoichiometry among populations of the Trinidadian guppy. Functional Ecology 26:666676.

$\rightarrow$ Elser, J. J., M. E. S. Bracken, E. E. Cleland, D. S. Gruner, W. S. Harpole, H. Hillebrand, J. T. Ngai, E. W. Seabloom, J. B. Shurin, and J. E. Smith. 2007. Global analysis of nitrogen and phosphorus limitation of primary producers in freshwater, marine and terrestrial ecosystems. Ecology Letters 10:1135-1142.

$\rightarrow$ Elser, J. J., R. W. Sterner, E. Gorokhova, W. F. Fagan, T. A. Markow, J. B. Cotner, J. F. Harrison, S. E. Hobbie, G. M. Odell, and L. J. Weider. 2000. Biological stoichiometry from genes to ecosystems. Ecology Letters 3:540-550.

$\rightarrow$ Elser, J. J., and J. Urabe. 1999. The stoichiometry of consumerdriven nutrient recycling: theory, observations, and consequences. Ecology 80:735-751.

$\rightarrow$ Flecker, A. S. 1996. Ecosystem engineering by a dominant detritivore in a diverse tropical stream. Ecology 77:1845-1854.

$\rightarrow$ Flecker, A. S., B. W. Taylor, E. S. Bernhardt, J. M. Hood, W. K. Cornwell, S. R. Cassatt, M. J. Vanni, and N. S. Altman. 2002. Interactions between herbivorous fishes and limiting nutrients in a tropical stream ecosystem. Ecology 83:1831-1844.

$\rightarrow$ Gido, K. B., and N. R. Franssen. 2007. Invasion of stream fishes into low trophic positions. Ecology of Freshwater Fish 16:457464.

$\rightarrow$ Grimm, N. B. 1988. Role of macroinvertebrates in nitrogen dynamics of a desert stream. Ecology 69:1884-1893.

$\rightarrow$ Gruner, D. S., J. E. Smith, E. W. Seabloom, S. A. Sandin, J. T. Ngai, H. Hillebrand, W. S. Harpole, J. J. Elser, E. E. Cleland, M. E. S. Bracken, E. T. Borer, and B. M. Bolker. 2008. A 
cross-system synthesis of consumer and nutrient resource control on producer biomass. Ecology Letters 11:740-755.

$\rightarrow$ Haag, W. R., and A. L. Rypel. 2011. Growth and longevity in freshwater mussels: evolutionary and conservation implications. Biological Reviews 86:225 247.

$\rightarrow$ Hall, R. O., J. L. Tank, and M. F. Dybdahl. 2003. Exotic snails dominate nitrogen and carbon cycling in a highly productive stream. Frontiers in Ecology and the Environment 1: 407-411.

$\rightarrow$ Hood, J. M., M. J. Vanni, and A. S. Flecker. 2005. Nutrient recycling by two phosphorus-rich grazing catfish: the potential for phosphorus-limitation of fish growth. Oecologia (Berlin) 146:247-257.

Hooper, D. U., E. C. Adair, B. J. Cardinale, J. E. K. Byrnes, B. A. Hungate, K. L. Matulich, A. Gonzalez, J. E. Duffy, L. Gamfeldt, and M. I. O'Connor. 2012. A global synthesis reveals biodiversity loss as a major driver of ecosystem change. Nature 486:105-108.

Kitchell, J. F., J. F. Koonce, and P. S. Tennis. 1975. Phosphorus flux through fishes. Verhandlungen der Internationalen Vereinigung für theoretische und angewandte Limnologie 19:2478-2484.

$\rightarrow$ Knoll, L. B., P. B. McIntyre, M. J. Vanni, and A. S. Flecker. 2009. Feedbacks of consumer nutrient recycling on producer biomass and stoichiometry: separating direct and indirect effects. Oikos 118:1732-1742.

$\rightarrow$ Kraft, C. E. 1992. Estimates of phosphorus cycling by fishes using a bioenergetics model. Canadian Journal of Fisheries and Aquatic Sciences 49:2596-2604.

$\rightarrow$ Liess, A., and M. Kahlert. 2009. Gastropod grazers affect periphyton nutrient stoichiometry by changing benthic algal taxonomy and through differential nutrient uptake. Journal of the North American Benthological Society 28:283-293.

$\rightarrow$ Malard, F., K. Tockner, M. J. Dole-Olivier, and J. V. Ward. 2002. A landscape perspective of surface-subsurface hydrological exchanges in river corridors. Freshwater Biology 47: 621-640.

McIntyre, P. B., and A. S. Flecker. 2010. Ecological stoichiometry as an integrative framework in stream fish ecology. Pages 539-558 in D. A. Jackson and K. B. Gido (editors). Community ecology of stream fishes: concepts, approaches, and techniques. American Fisheries Society, Bethesda, Maryland.

$\rightarrow$ McIntyre, P. B., A. S. Flecker, M. J. Vanni, J. M. Hood, B. W. Taylor, and S. A. Thomas. 2008. Fish distributions and nutrient cycling in streams: can fish create biogeochemical hotspots? Ecology 89:2335-2346.

$\rightarrow$ McIntyre, P. B., L. E. Jones, A. S. Flecker, and M. J. Vanni. 2007. Fish extinctions alter nutrient recycling in tropical freshwaters. Proceedings of the National Academy of Sciences of the United States of America 104:4461-4466.

$\rightarrow$ Nico, L. G., and R. T. Martin. 2001. The South American suckermouth armored catfish, Pterygoplichthys anisitsi (Pisces: Loricariidae), in Texas, with comments on foreign fish introductions in the American southwest. Southwestern Naturalist 46:98-104.

$\rightarrow$ Ricciardi, A., and J. B. Rasmussen. 1999. Extinction rates of North American freshwater fauna. Conservation Biology 13: 1220-1222.

Rugenski, A. 2013. Influences of disease-driven amphibian declines on ecosystem structure and function in Panamanian headwater streams. PhD Dissertation, Southern Illinois University, Carbondale, Illinois.

$\rightarrow$ Rugenski, A. T., C. Múrria, and M. R. Whiles. 2012. Tadpoles enhance microbial activity and leaf decomposition in a neotropical headwater stream. Freshwater Biology 57:19041913.

Sereda, J. M., J. J. Hudson, W. D. Taylor, and E. Demers. 2008. Fish as sources and sinks of nutrients in lakes. Freshwater Biology 53:278-289.

$\rightarrow$ Small, G. E., A. M. Helton, and C. Kazanci. 2009. Can consumer stoichiometric regulation control nutrient spiraling in streams? Journal of the North American Benthological Society 28:747765.

$\rightarrow$ Small, G. E., C. M. Pringle, M. Pyron, and J. H. Duff. 2011. Role of the fish Astyanax aeneus (Characidae) as a keystone nutrient recycler in low-nutrient Neotropical streams. Ecology 92:386-397.

$\rightarrow$ Spooner, D. E., and C. C. Vaughn. 2009. Species richness and temperature influence mussel biomass: a partitioning approach applied to natural communities. Ecology 90:781-790.

$\rightarrow$ Spooner, D. E., C. C. Vaughn, and H. S. Galbraith. 2012. Species traits and environmental conditions govern the relationship between biodiversity effects across trophic levels. Oecologia (Berlin) 168:533-548.

Sterner, R. W., and J. J. Elser. 2002. Ecological stoichiometry: the biology of elements from molecules to the biosphere. Princeton University Press, Princeton, New Jersey.

$\rightarrow$ Strayer, D. L. 2009. Twenty years of zebra mussels: lessons from the mollusk that made headlines. Frontiers in Ecology and the Environment 7:135-141.

$\rightarrow$ Strayer, D. L. 2010. Alien species in fresh waters: ecological effects, interactions with other stressors, and prospects for the future. Freshwater Biology 55:152-174.

$\rightarrow$ Strayer, D. L. 2012. Eight questions about invasions and ecosystem functioning. Ecology Letters 15:1199-1210.

$\rightarrow$ Strayer, D. L. 2013. Understanding how nutrient cycles and freshwater mussels (Unionoida) affect one another. Hydrobiologia 735:277-292.

$\rightarrow$ Strayer, D. L., and D. Dudgeon. 2010. Freshwater biodiversity conservation: recent progress and future challenges. Journal of the North American Benthological Society 29:344358.

$\rightarrow$ Taylor, B. W., C. F. Keep, R. O. Hall, B. J. Koch, L. M. Tronstad, A. S. Flecker, and A. J. Ulseth. 2007. Improving the fluorometric ammonium method: matrix effects, background fluorescence, and standard additions. Journal of the North American Benthological Society 26:167-177.

Thurow, R. F. 1994. Underwater methods for study of salmonids in the intermountain west. General Technical Report INT GER 307. Intermountain Research Station, US Department of Agriculture Forest Service, Ogden, Utah.

$\rightarrow$ Vanni, M. J. 2002. Nutrient cycling by animals in freshwater ecosystems. Annual Review of Ecology and Systematics 33: 341-370.

$\rightarrow$ Vanni, M. J., G. Boros, and P. B. McIntyre. 2013. When are fish sources versus sinks of nutrients in lake ecosystems? Ecology 94:2195-2206.

$\rightarrow$ Vanni, M. J., A. M. Bowling, E. M. Dickman, R. S. Hale, K. A. Higgins, M. J. Horgan, L. B. Knoll, W. H. Renwick, and R. A. Stein. 2006. Nutrient cycling by fish supports relatively 
more primary production as lake productivity increases. Ecology 87:1696-1709.

$\rightarrow$ Vanni, M. J., A. S. Flecker, J. M. Hood, and J. L. Headworth. 2002. Stoichiometry of nutrient recycling by vertebrates in a tropical stream: linking species identity and ecosystem processes. Ecology Letters 5:285-293.

$\rightarrow$ Vaughn, C. C. 2010. Biodiversity losses and ecosystem function in freshwaters: emerging conclusions and research directions. BioScience 60:25-35.

$\rightarrow$ Vaughn, C. C., K. B. Gido, and D. E. Spooner. 2004. Ecosystem processes performed by unionid mussels in stream mesocosms: species roles and effects of abundance. Hydrobiologia 527:3547.

Vaughn, C. C., and J. P. Julian. 2013. Incorporating ecological costs and benefits into environmental flow requirements for Oklahoma rivers: Phase 1, Southeastern Oklahoma. Page 38 in Oklahoma Water Resources Research Institute (editor). Oklahoma Water Resources Research Institute, Norman, Oklahoma. (Available from: http://ojs.library.okstate.edu/osu/index .php/OWRRI/article/viewFile/1686/1527) $\rightarrow$ Vaughn, C. C., and D. E. Spooner. 2006. Unionid mussels influence macroinvertebrate assemblage structure in streams. Journal of the North American Benthological Society 25:691700.

Weber, C. 1991. New taxa in Pterygoplichthys S I (Pisces, Siluriformes, Loricariidae). Revue Suisse De Zoologie 98:637-643.

$\rightarrow$ Whiles, M. R., R. O. Hall, W. K. Dodds, P. Verburg, A. D. Huryn, C. M. Pringle, K. R. Lips, S. S. Kilham, C. Colon-Gaud, A. T. Rugenski, S. Peterson, and S. Connelly. 2013. Disease-driven amphibian declines alter ecosystem processes in a tropical stream. Ecosystems 16:146-157.

$\rightarrow$ Whiles, M. R., K. R. Lips, C. M. Pringle, S. S. Kilham, R. J. Bixby, R. Brenes, S. Connelly, J. C. Colon-Gaud, M. HunteBrown, A. D. Huryn, C. Montgomery, and S. Peterson. 2006. The effects of amphibian population declines on the structure and function of Neotropical stream ecosystems. Frontiers in Ecology and the Environment 4:27-34.

$\rightarrow$ Wilson, H. F., and M. A. Xenopoulos. 2011. Nutrient recycling by fish in streams along a gradient of agricultural land use. Global Change Biology 17:130-139. 